István Talabos

Senior Lecturer at Budapest Business School College of Commerce, Catering and Tourism and a PhD student of the Szechenyi Istvan University of Györ, Hungary

UDC 338.48(497.11 Podunavlje)

\title{
CUSTOMER HABITS AND THE DATOURWAY ${ }^{1}$ STRATEGY
}

\begin{abstract}
The different funds of European Union - ISPA, PHARE, SAPARD - ensured the possibility not only to work out developing projects, but also they provided possibility to realize them. ${ }^{1}$

These funds' aim was rural development, spatial development, development of economy but tourism has never been nominated.

After the year of 2004 tourism received attention and several funds of European Union aimed at development of infrastructure for tourism, development of thematic routes, development of accommodation, etc. ${ }^{2}$

There were several strategies prepared for the Danube, and the Datourway project had its special name: Transnational Strategy for the Sustainable Territorial Development of the Danube Area with special regard to Tourism. ${ }^{3}$
\end{abstract}

1 DATOURWAY: The first tourism strategy project (2009-2012) of the Danube region within the SEE Transnational Cooperation Programme that aimed specially at the development of tourism.

2 Note: This was the time when Tourism Destination Management came in focus in Hungary.

3 The total fund of the project: EUR 2,888,952. Participants: 16 institutions of 7 countries prepared the strategy and a development for tourism for the participating countries.
The Danube is undervalued from the tourism point of view. In the participating countries the capitals, seaside, beaches, mountains are considered real attractions and it means that the tourism strategy for the Danube is a challenging task.

The final and main outcome is not only the strategy for tourism considering the customer habits, but an Investment Guide Book pointing out the common values of destination and attraction development together with "best practices" common projects for the different types of regions too, in order to serve the development of Danube Region.

Key words: Danube, development of destination, brand, sustainability, tourism potential 


\section{Introduction}

Tourism is unavoidable and it is part of our everyday life today (Tamas 1981 after Happ 2011) playing an important role both socially and economically. To be competitive is the key of the success and competitiveness is one of the main issues that regional sciences focus on.

Tourism is an important economical factor as the comprised contribution to the GDP is $9 \%$ (WTTC, 2012) globally, but in some countries it reaches and exceeds $10 \%$.

Tourism is also mentioned frequently as the "world's largest industry" that is growing fast. In 1950 only, 25 million arrivals (people crossing the borders) were registered (Poon, 1993, p. 7). In 1971, international tourism generated USD 20 billion income (Kapalyag, 1998 , p. 30) but at the start of the $21^{\text {st }}$ century international tourism already generated well over USD 450 billion and looking at the production of the international and domestic tourism we can mention USD 3.5 trillion, whereas the annual growth is estimated at about $4 \%$ (Sharpley-Telfer, 2002, p. 1) UNWTO states that "...Tourism has become one of the major players in international commerce..." and its importance - contribution to the GDP - just a little bit behind of the bank sector. On Figure 1, we compare tourism and its contribution to GDP with automotive and banking sector.
Figure 1: GDP contribution by sector ${ }^{4}$

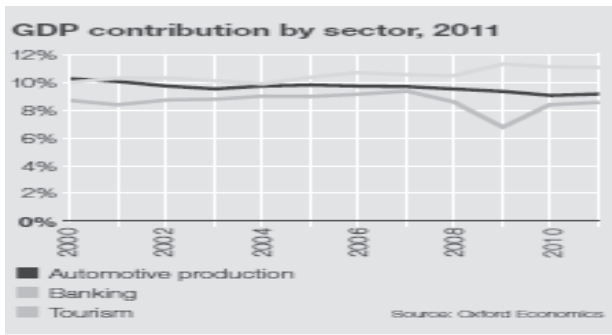

Source: WTTC Travel\&Tourism, 2011.

\section{Tourism - Customer habits}

Tourism is growing and expanding, and the growth and expansion are obvious because the tourist arrivals in 2012 went to 1035 million according to UNWTO and USD 650 billion investment is related to the tourism industry which is $4.5 \%$ of all of the world's (WTTC, 2011).

Tourism is not only important but it is a complex system. The complexity is underlined by several authors ${ }^{5}$ - Marton Lengyel, Wilhelm Pompl, Laszlo Putzko, Claude Kaspar etc.

The tourism is not only a complex system but after Richard Butler in Babu- Mishra Parida (2008, p. 54) it is "a large and complex phenomenon". As of the complexity it has economic, cultural, political, environmental and sociocultural implication.

4 Note of the author: According to the Central Statistical Office (CSO) of Hungary the contribution of tourism to the GDP is about 5-8 \% and according to the Satellite Account (2007) prepared by CSO of Hungary tourism's employment rate is $8.4 \%$ meaning 323,000 employees. In Bulgaria the same rate is 2.8 $\%$ (2010). For other Datourway countries the information was not available.

5 The list of authors is not complete and the nature of this paper does not require a full list (Talabos I.) 
There is not only the tourist in this system but the attraction, service providers and the environment. Figure 2 shows the relationship and complexity of the tourism.

Figure 2: System of Tourism

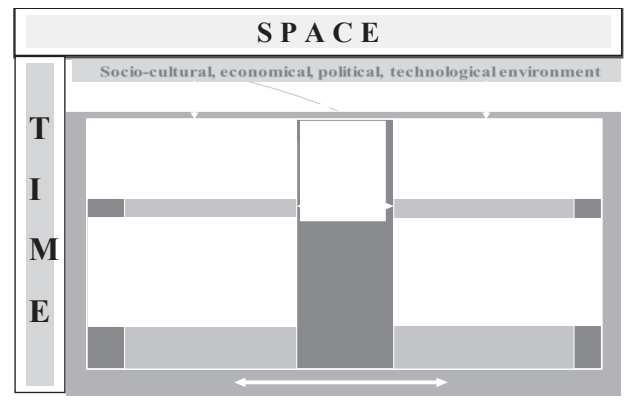

Source: The author according to Jenkei, 2002, Pompl, 1, 2000, p. 21, Pompl, 1, 2000, and Bridging $^{6}$ 2010, p. 4.

Globalization plays an important role for the economy of the entire world but it plays a special role for the tourism as tourism is related to several sectors and fields of economy.

“The UNWTO (1998) identifies seven industrial categories based on 'tourism consumption by major function' whereas the US Standard Industrial Classification System records more than 35 different major industrial components that serve the traveller (Roehl, 1998)" cites Babu (2008) in BabuMishra-Parida (2008, p. 44).

The tourism can and should be investigated in accordance with regional sciences as Pompl (2000) described the system of tourism identifying 4 factors after Porter's model which has been completed by the author from the tourism product point of view including the potential service providers too (See Figure 2), and should we think further on in accordance with regionalism

6 Note: The author is the owner and project manager of Bridging Marketing Consulting preparing several development studies and strategies for tourism and regional development. and adding the "space" as the environment surrounding us, plus the time to the system as Dr. Jenkei (2002) included in his sociological approach we really come to a complex system of tourism as shown on Figure 2.

After the Second World War tourism started to develop as a result of social, technological and political influences, and about 20 years was enough and the tourism industry became mass with the meaning in the early 1980s "that mass tourism was the best practice"(Poon, 1993, p. 4).

"An understanding of different tourist roles and categories is a prerequisite to the explanation and prediction of tourist behaviour (Sharpley, 1994). There are nonetheless no standard or universally accepted categories for defining tourists." (Mehmetoglu, 2004)

Tourism is present in our everyday activity and it is unavoidable. Nowadays, we know undoubtedly that the people are in the centre of the tourism as human beings (Tasnadi, 2001). The globalization had great impact on the culture, fashion and the customers started to pay more attention to the "free time" activities (Jozsa, 2001) and due to the globalization, the change of technology and economy the customer habits also changed (Bodis, 2013, Tasnadi, 2001, Töröcsik, 2012).

The fundamental of the tourism growth is the customer behaviour, the customer habits. It is permanently changing and from the end of the Second World War to the 1990 , we can speak about the change i.e. emergence of new tourism due to change in the customer' habits.

The customer habits of the tourist have been researched in the last decades more intensively with the special attention to the motivation, attitudes, perception and also the "tourist and the host relationship" cites Cohen (1984) by Happ (2011).

One of the major focus of these works and researches is the sociological approach states Happ (2011, p. 13) after Cohen 1972, 
1979, 1984, Maccannell 1976, De Kadt 1979, Urry 1990, Lanfant 1993, Sharpley 1994, Apospoulos Et Al 1996, Rojek \& Urry 1997.

The change of times resulted in change of lifestyle, travel experience, change in the income resulted in a new type of traveller (Poon, 1993) i.e. the emergence of new tourism.

The new tourism means new demands. The tourist refers to a customer who is flexible, has experience and is independent (Poon, 1993) and at the same time customers are more and more demanding, they wish to be active participants (Arva - DeliGray, 2011).

This resulted in the following change:

Graph 1: Characteristics of old tourist versus new tourists

\begin{tabular}{|l|l|}
\hline \multicolumn{2}{|c|}{ CONSUMER/TOURIST } \\
\hline \multicolumn{1}{|c|}{ OLD } & \multicolumn{1}{c|}{ NEW } \\
\hline Inexperienced & Mature \\
\hline Homogeneous & Hybrid \\
\hline Predictable & Spontaneous \\
\hline Sun-lust & Sun-plus \\
\hline Get sunburnt & Keep clothes on \\
\hline Security & Want to be different \\
\hline Superiority & Understanding \\
\hline Escape & Extension of life \\
\hline
\end{tabular}

Source: Poon (1993, p. 91)
Customer habits of tourists, their requirements and judgement are changing permanently. There are several factors influencing it: i.e the social, economic, technological requirements etc. Among the factors we have to mention the fashion too, but this paper's focus is different, therefore we do not go into details of this issue here.

Tourists are looking for a special product that is individual, tailor-made cites Kiss (2001). Reiner-Taurer (1999) and the tourists prefer individual travel and not mass tourism, they want to become active participants (Arva-Deli, 2011).

Effect of the globalisation is the change in the customer behaviour, customer habits and attitudes, which means that the tourist:

- looks for experience

- is sensitive to local cultures

- is more independent minded

- prefers flexible and spontaneous itineraries

- wishes to have a positive impact on the destination

- carefully approaches tourism product in advance

- buys on internet

- looks for information and ask others opinion on the internet

and as of this, the attraction plays an important role. The attraction is in the focus that initiates and generates tourism. (Weaver-Oppermann, 2000, p. 357, Vassné Egri - Danó, 2012)

Graph 2: The change of customer requirements

\begin{tabular}{|l|l|l|}
\hline Field & New Tourism & Old Tourism \\
\hline Accommodation & $\begin{array}{l}\text { Guest house, private acc. } \\
\text { (zimmer frei), pansion }\end{array}$ & Hotel belonging to a hotel chain \\
\hline Gastronomy & $\begin{array}{l}\text { Small pubs with local food } \\
\text { and dishes }\end{array}$ & $\begin{array}{l}\text { International restaurants and } \\
\text { dishes }\end{array}$ \\
\hline Souvenirs (preparing) & handcrafts & mass production \\
\hline Transport & $\begin{array}{l}\text { Individual transportation (car } \\
\text { etc.) }\end{array}$ & Air -conditioned bus, coach. \\
\hline
\end{tabular}

Source: Bridging (2006) Mowforth and Munt, 2003

based on Szemelvények, 2006/1, p. 9 
The genius loci (spirit of the place) and the identity is the key (Aubert, 2006) of the tourist product and in order to succeed i.e. to attract the tourist, to get to make decision to spend his money the attraction is the key.

Beside it seasonality, the target group, customer habits and the price play and important role, but to be successful considering all of this there must be a complex tourist product. The attraction raises the interest and other elements (transportation, services - acc. meals etc. - infrastructure) help the service provider that the tourist would make a decision.

In the decision making process the customer is active, looking for the necessary for him information.

Another very important factor is the internet because in this process the internet plays the most important role. The internet and the friends, relatives role in the decision making is $50 \%$ meaning that the final decision is influenced in $50 \%$ by friends, relatives and of course the internet (Neulinger - Kelemen - Simon - Hofmeister, 2009).

The conference participants in Bourdeaux, held on 17-19 September 2008, stated clearly that in order to reach the customer new technological results (mobile telephone, smartphones etc.) have to be applied and used because the mobile technology is $85.7 \%$ widespread worldwide (ITU, 2012).

We should not forget about the importance of the trust and trustworthiness which is a decisive factor in the decision making process of the tourist together with the image and the brand that helps the trustworthiness because the thoughts, associations' are the elements of the image (Zavodnyik, 2005, p. 65 after Brochard-Lendrevie, 2004, p. 126) while, at the same time, the "role of the brand is to reinforce the customer in the decision and generate a new transaction" (Zavodnyik, 2005, p. 66).

\section{The Datourway project - Main findings}

Europe is an important tourism destination because appr. $50 \%$ of the tourist arrivals and international tourist receipts are realized on the continent. Of course, the European Union tourism is has a key position because there are 1.8 million enterprises having relationship to the tourism, providing 9.7 working places and contributing indirectly $10 \%$ the GDP.

The Danube is a $2,800 \mathrm{~km}$ long water route going through 10 countries before it reaches the Black Sea.

Over the last several years, there were several European projects aiming to develop the Danube Region (Europeanization of the Danube Region: The Blue Ribbon Project, European Danube Strategy, Donauregionen+ and Donauregionen++) but there was no one prepared with the focus for the touri$\mathrm{sm}$. It is the Datourway project which is the first of its kind.

The entire project aimed to contribute to the sustainable spatial development of the Danube region outlining a common strategy main frame of which could be applied and used in the participating countries.

The seven participants of the project: Slovakia, Hungary, Romania, Bulgaria, Serbia, Croatia and Italy and 16 partner institutions of the participating countries strongly cooperating and working together formed a common strategy and for each participating country an Investment Guide Book has been prepared.

In the project only $2 / 3$ of the "Danube countries" but nevertheless preparing a common strategy was a real challenge to find the common platform in these differently developed countries and even the structural set up and approach of tourism is different. Not talking about facts that some of the participating countries (e.g. Bulgaria, Croatia) focus on the beach. Italy has been participating because the Danube region countries wanted to learn "Best practices" cases about the Po Delta. 


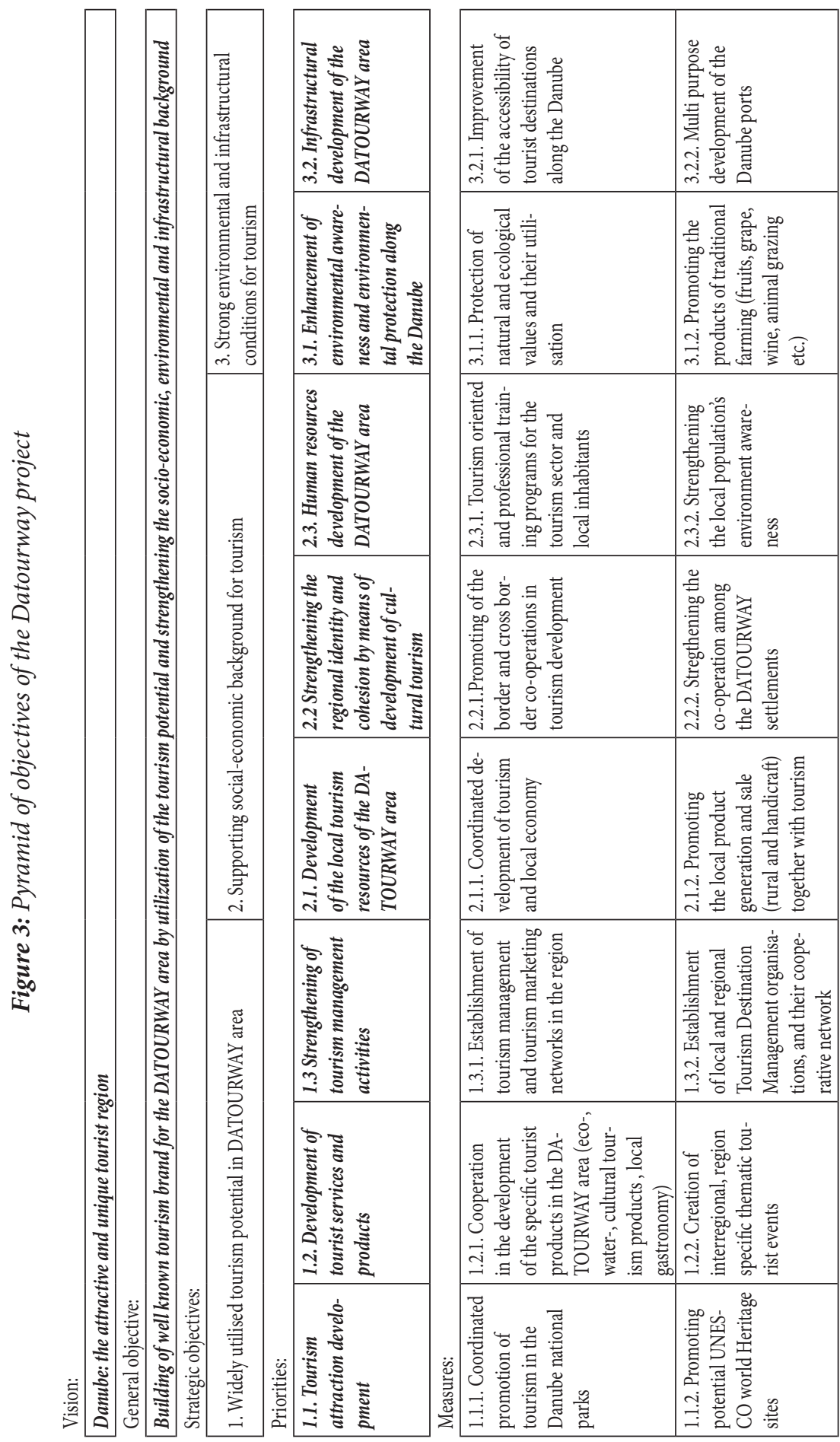




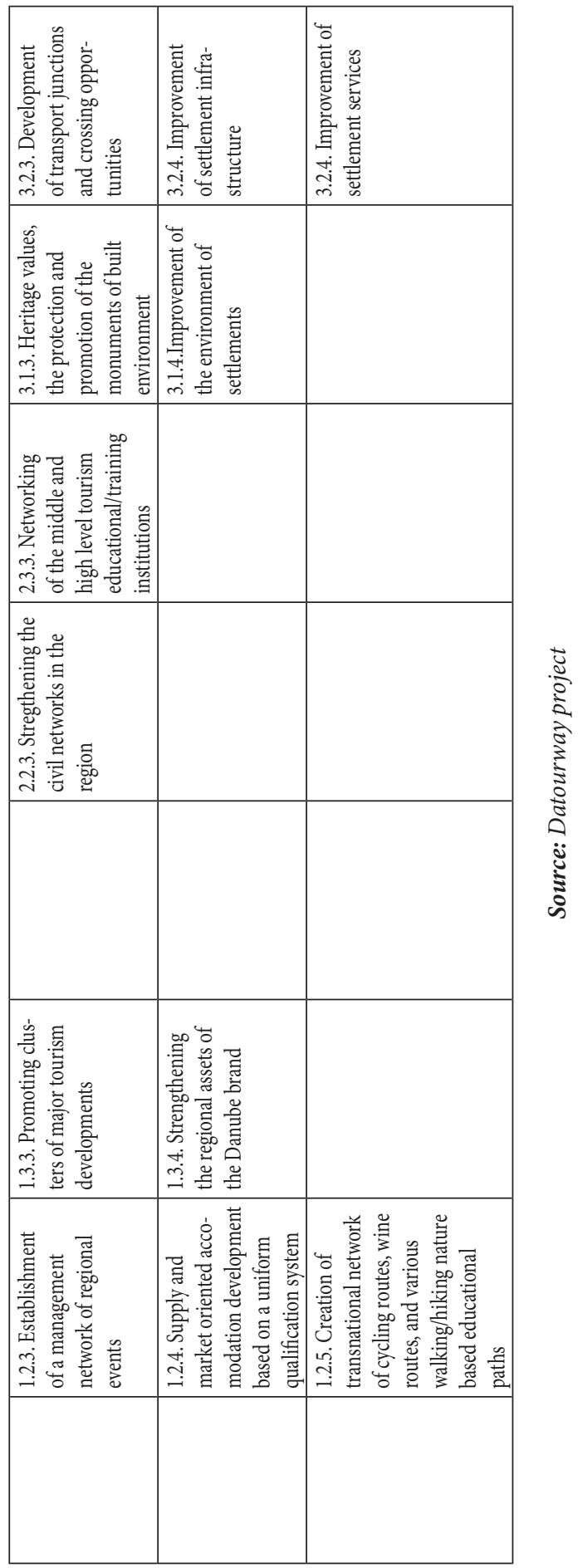




\section{The Datourway project strategy}

Lead partner of the project was VÁTI Hungarian Nonprofit Ltd. Company for Regional Development and Town Planning. Its main partner Scientific Association for Spatial Development was responsible for working out the strategy ${ }^{7}$.

The prepared strategy based on an evaluation focusing on the tourist product. The main aim the General Objective of the strategy accepted and approved by the participants:

"Building of a well-known tourism brand for the Danube region by utilization of the tourism potential and strengthening the socio-economic, environmental and infrastructural background"

\section{as the VISION}

\section{"Danube the attractive and unique tourist region"}

defining 3 clear strategic objectives:

1. Widely utilised tourism potential in $\mathrm{Da}$ tourway area

2. Supporting social-economic background for tourism

3. Strong environmental and infrastructural conditions for tourism

This means that each country had to prepare an inventory of the attractions as the focus was put on the tourist product which means that the attraction which arises the interest of the tourist to which the services must be added with transportation (Figure 2)

Main aim of Scientific Association for Spatial Development while outlining the strategy was to have a common platform for each participant that could be applied on a local level.

The outcome is Figure 3.

Note: the author has been participating in the project as a consultant and delivered lectures during workshops.
The formed strategy does not tell exact tourist product because it will be different all over the Danube depending on the potential i.e. attractions.

Should we want to be successful we need to think in terms of complex tourist product, thematic routes, we need to apply and take advantage of the latest technological achievements and at the same time creativity is also required because the range of attraction is very wide.

It is enough for example to think about a recently coming up new "fashion" the geocaching.

Many areas of the Danube provide excellent potential for this and other attractions that could be the base of the touristic product.

\section{Summary}

Considering the direct and indirect effects of tourism the contribution to the GDP was $9.1 \%$ (www.unwto.org) in 2011 and $9 \%$ in 2012 (www.wttc.org).

The Danube, the main river in Central Europe is the focus of attention because of logistics, transportation, water management, renewing source of energy but with the $\mathrm{Da}$ tourway project tourism has also been brought into focus.

"...The concept of tourism is interpreted in the project in a broad sense. It is regarded as a complexity of activities serving for recreation, resort and leisure, cultural enrichment, enjoyment of natural beauty of physical exercise. The aim of the project is to enhance and promote transnational cooperation to promote and mobilize the various tourist potentials of the river itself, of the riverbanks as well as of the natural beauty of the riverside area and architectural assets of the lively towns, cities and villages by the Danube..." (Datourway Strategy, 2011, p. 5)

The project pointed out that in the neighbouring countries of Hungary along the 
Danube development of tourism also in the focus of the attention and in order to achieve result the cooperation of the "Danube countries" is a must.

Strengthening the cooperation and improving accessibility by developing transport links as well as pointing out the built heritage, local and regional traditions lead to success.

One of the main achievements of the Datourway projects is that the concept of tourism is interpreted in a broad sense meantime the customer habits are taken into consideration i.e. the brand and image helps to attract tourist to the destination therefore each country has to focus on the destination management not forgetting the new technological means the mobile phones and the internet.

\section{References}

Aubert, A. (2006) Desztináció épités és menedzsment (Destination development and management), Dél-dunántúli Turizmus Kiskönyvek.

Babu, S. S, Mishra, S. and Parida, B. B. (Eds.) (2008) Tourism Development Revisited - Concepts, issues and paradigms, Delhi.

Capio, J. and Valle, E. (2008) The macroeconomic contribution of tourism in Tourism Development, Economics, Management and Strategy. New York.

Happ, E. (2011) Fogyasztoi magatartás vizsgálata nemzetközi konferenciák magyarországi piacán (Investigating customer habits of the conference visitors on the Hungarian market), Értekezés doktori (PhD) fokozat elnyerése érdekében. Sopron.

Jenkei, L. (2002) Értekezés a turizmus elméletének szociológiai irányzatáról BGF KVIFK (Essay about the sociological trend of tourism). Budapest Business School College of Commerce Catering and Tourism: Budapest.
Jozsa, L. (2001) Stratégia és kultúra (Strategy and culture). Marketing\&Menedzsment, 1.

Kapalyag, I. (1998): Tanuljunk turizmusul (Let's learn tourism). Budapest.

Mehmetoglu, M. (2004) Tourist or traveller? - A typological approach. Tourism Review Vol. 59 (3), 33-39.

National Analytical Report on the Bulgarian Part of the Transnational Project Area (2010). In Work Package 3 of the Datourway project "Territorial surveying and evaluation(Analyses)". Datourway.

Neulinger, Á., Kelemen, K., Simon, J., Hofmeister T. Á. (2009) Fogyasztói magatartás a hazai utazási szolgáltatások piacán (Customer behaviour on the domestic travel service market). Turizmus Bulletin XIII. évf. 4. szám 44-55 o.

Poon, A. (1993) Tourism, Technology and Competitive Strategies. CABI.

Sharpley, R. and Telfer, D. J. (Eds.) (2002) Tourism and development - Concepts and issues. Channel View Publications by Cambrian Printers: Aberystwyth.

Talabos, I. (2012) Outputs of the Datourway project. Conference presentation on $1^{\text {st }}$ February, Samorin.

Talabos, I. (2011) Destination management (Tourism planning). Big River and Network Building Conference, 24-25 November: Sofia.

Talabos, I., Csutorás, É., Talabos G., Boglárka K. (2006) Piackutatás és Marketing terv I. II., Dunakanyar Kulturális Alapítvány (Market Research and Marketing Plan No. 1-2 for the Cultural Foundation of the Danube Bend). Budapest.

Tasnadi, J. (2001) Turizmus az Európai Unióban és Magyarországon (Tourism in EU and in Hungary). MKIK : Budapest.

Torocsik, M. (2012) A megváltozott fogyasztó - jellemzők, elvárások, reakciók ea. (Change in customer's behaviour - characteristics, what is awaited, reactions). A Marketing új tendenciái c. konferencia (New tendencies of marketing - conference plenar session lecture) : Győr. 
Travel and Tourism Economic impact (2013) European Union WTTC : London.

Vasné, E. M. and D. G. (2012) A hazai e-vásárlási szokások fó jellemzői, azok dinamikája (Main characteristics of the local (Hungarian) e-shopping and its dinamics). Konferencia előadás és kötetben megjelenő cikk "A válság hatása a kiskereskedelemre" - Tudományos Konferencia : Gödöllő.

Weaver, D. and Oppermann, M. (2000) Tourism Management. John Wiley and Sons.
Zavodnyik, J. (2005) A kiszolgáltatott e-fogy@ sztó (The defenseless e-customer). Marketing \& Menedzsment, 4-5, 55-71.

www.ksh.hu

www.unwto.org

http://www2.unwto.org/en/content/why-tourism (accessed on March 24th, 2013) www.wttc.org

http://kgk.sze.hu/images/dokumentumok/ kautzkiadvany2011/marketing/ÁrvaL_ DeliZs.pdf

(accessed on November 16th, 2012)

www.datourway.eu 